\title{
The Investigation of Caregiving Burden and Life Quality of Caregivers Who Care for Cancered Patients
}

\section{Kanserli Hastalara Bakım Veren Bireylerin Bakım Yükü, Yaşam Kalitesi ve Etkileyen Faktörlerin İncelenmesi}

\author{
Sibel CEYLAN GÜR ${ }^{1}$ (D), Fatma ERSIN² \\ 1 Provincal Health Directorate Mehmet Akif Inan Training Research Hospital, Sanliurfa, TURKEY \\ ${ }^{2}$ Harran University Faculty of Health Sciences, Department of Public Health Nursing, Sanliurfa, TURKEY
}

\section{Abstract}

Background: Caring for cancer patients affects both the care burden and quality of life of the caregivers. This study was conducted to determine the care load, quality of life of caregivers who care for cancer patients and the influencing factors.

Materials and Methods: This descriptive research which used the Questionnaire Form, Caregiver Quality of Life Index-Cancer Scale and Zarit Caregiver Burden Scale.160 caregivers who agreed to participate in the study composed the sample. In the analysis of the data, descriptive statistics (number, percentage, mean), Independent Samples t test, Kruskal Wallis test, Mann Whitney U test were used.

Results: The mean total burden interview scale score of caregivers was $32.65 \pm 15.14$ and the mean total caregiver quality of life Index-cancer scalescore was $78.75 \pm 16.31$. It was found that there was a statistically significant difference between the mean total caregiver burden scores according to gender and marital status $(p<0.05)$. There were statistically significant differences between the mean total caregiver burden scores according to the negative affection status of health during caregiving and the mean total life quality scores according to the income stasus $(p<0.05)$.

Conclusions: It was determined that the individuals providing care had a mild level of care burden and their quality of life was not at the desired level. For this reason, it may be suggested to carry out the care burden at the desired level and to conduct interventional nursing studies to improve the quality of life.

Key Words: Cancer, Care burden, Quality of life, Nursing.

öz.

Amaç: Kanserli hastaya bakım vermek, bakım vericilerin hem bakım yüklerini hem de yaşam kalitesini etkilemektedir. Bu çalışma, kanser hastalarına bakım verenlerin bakım yükü, yaşam kalitesi ve etkileyen faktörleri belirlemek amacıyla yapılmıştır.

Materyal ve Metod: Tanımlayıcı tipte olan çalışmada, Anket Formu, Kanserli Hastalara Bakım Verenlerde Yaşam Kalitesi Ölçeği ve Zarit Bakım Verme Yükü Ölçeği kullanılmıştır. Çalışmanın örneklemini 160 bakım veren oluşturmuştur. Verilerin analizinde tanımlayıcı istatistikler (sayı, yüzde, ortalama), bağımsız gruplarda t testi, Kruskal Wallis testi, Mann Whitney $U$ testi yapılmıştır.

Bulgular: Bakım veren bireylerin bakım verme yükü ölçeği toplam puan ortalamaları $32.65 \pm 15.14$, yaşam kalitesi ölçeği toplam puan ortalamaları ise $78.75 \pm 16.31$ 'dir. Hasta bireylerin cinsiyet ve medeni durumuna göre bakım verme yükü toplam puan ortalamaları arasında anlamlı bir fark saptanmıştır $(p<0.05)$. Bakım verirken sağlığın olumsuz etkilenme durumuna göre bakım verme yükü toplam puan ortalamaları ve gelir durumuna göre yaşam kalitesi toplam puan ortalamaları arasında istatistiksel olarak anlamlı bir fark saptanmıştır ( $\mathrm{p}<0.05)$.

Sonuç: Çalışmada bakım veren bireylerin hafif düzeyde bakım yükünün olduğu ve yaşam kalitesinin istenen düzeyde olmadığı saptanmıştır. Bu nedenle bakım yükünün istendik düzeyde devam etmesi ve yaşam kalitesini yükseltmeye yönelik girişimsel hemşirelik çalışmalarının yapılması önerilebilir.

Anahtar kelimeler: Kanser, Bakım yükü, Yaşam kalitesi, Hemşirelik
Corresponding Author / Sorumlu Yazar

Fatma ERSiN

Harran University Faculty of Health

Sciences, Department of Public Health

Nursing, Sanliurfa, TURKEY

E-mail: fatmaersin1@gmail.com

Received / Geliş Tarihi: 05.01.2021

Accepted / Kabul Tarihi: 15.03.2021

DOI: $10.35440 /$ hutfd 854215

This article is derived from the master thesis of Sibel CEYLAN GÜR. In addition, it was presented as a oral presentation (abstract) in the 1st International 2nd National Public Health Nursing Congress. 


\section{Introduction}

In developed and developing countries, cancer is an important public health problem which has a dramatically increasing incidence. It is the second most common cause of death after heart diseases in Turkey and in the World (1). The rapidly increasing number of cancer cases, the development of diagnosis and treatment methods, and the prolongation of the lifespan of patients cause the family members to have a primary role in care process and patients to take more responsibility in care $(2,3)$. Therefore, care burden of caregivers increases while their life quality decreases because cancer can affect the psychological health, economic, physical and social status of the family members who care with the patient negatively due to disease process, problems related to the treatment, and high cost (4).

In the studies, it was stated that there are many factors that affect the care burden and life quality of individuals who provide care for cancer patients (5-7). Orak and Sezgin (7) found that the education level, gender and duration of caregiving which are among the factors affecting the care burden of individuals providing care to the patients with cancer (7). In another study, it was stated that caregivers with low education level had more emotional distress, their lives were affected more and their health burdens were worser compared to caregivers with their higher education level (5). In the study of Karabuğa and Pınar, the gender of the caregiver, the gender of the patient, the presence of other caregivers in the family, economical status, old age and inability to fulfill their responsibilities, severe deterioration in physical health due to providing long-term care, anxiety, depression were found as the reasons affecting the quality of life in the family members providing care for the patient (6). In the studies, it was found that caregivers who have difficulties in fulfilling their responsibilities and who do not receive support from other family members have decreased life quality $(4,5,8,9)$. Nursing services play an important role in reducing the burden of care and improving the quality of life of individuals providing care for cancer patients. While patients and their caregivers struggle with a difficult disease, the need for nurses increases (10). In a study conducted by Aktaş et al. (11) it was suggested that it is very important that nurses are in cooperation with the family members providing care and benefit from their support and it is also important that nurses provide consultance about the time and place of the guidance and assistance services the caregiver needs. It is also beneficial that nurses provide feedback to caregiving family mrembers that their feelings are normal and they do their best, divide the problems experiencing by caregiving family mrembers into resolvable parts and help them to identify the resources and appropriate options (11).

In conclusion, although there are studies on the care burden of individuals providing care for cancer patients in the world and in Turkey $(3,12,13-16)$, there were limited number of studies towards life quality $(6,8,17,18)$ at the time of the study. Therefore, this study was carried out to determine care burden, quality of life of caregiving family members and the affecting factors.

\section{Materials and Methods Research design and sampling}

It is a descriptive study. The study was conducted between October 2016 - April 2017 with the individuals caring for cancer patients who were treated in the a hospital. The universe of the study consisted of 202 caregivers. The sampling method was not used in the study and it was aimed to reach the whole universe, but 160 caregivers who agreed to participate in the study composed the sample.

\section{Data collection tools}

Caregiver identification form: It was prepared by the researchers in order to determine the demo-graphic and care related characteristics of participants. It consists of 18 questions.

The caregiver quality of life index-cancer (CQOLC) scale: The Caregiver Quality of Life Index-Cancer was developed by Weitzner et al. (16) in 1999 and measures the quality of life of caregivers for cancer patients. It's Turkish validity and reliability study was conducted by Karabuga and Pınar in 2013 (6). It is a 5 point Likert-type assessment and each item is scored from 0 to 4 ( $0=$ none, $1=$ low, 2 = a little, 3 = high, 4 = very high). The raw score for each sub-scale is multiplied by 35 to 14 , divided by the number of expressions answered and the score of the sub-dimensions is determined. The score on the whole scale is calculated by summing the scores for the answers given to the 4 subdimensions and the answers given to the 8 expressions, in other words it is calculated by summing the scores of the answers given to all expressions in the scale multiplied by 35 and divided by the number of expressions. With this scoring method, the score of the each sub-scale and scale varies between 0 and 140. A higher score indicates a better quality of life $(6,16)$. The Cronbach's alpha value of the scale is 0.88 (6). In this study, Cronbach's alpha value was found to be. 90 for the quality of life scale.

Burden interview: It was developed by Zarit, Reever and Bach-Peterson in 1980 and identifies the difficulties experienced by caregivers (17). The Turkish validity and reliability study was conducted by Inci and Erdem in 2006 and consistsof 22 statements determined the effect of caregiving on caregivers lives (physical, mental and social wellbeing) (18). It is a 5-point Likert-type scale, each item is scored from 0 to 4, "never", "rarely", "sometimes", "often", "always". A minimum score can be obtained from the scale is 0 while maximum score is 88 . The score intervals are determined as $0-20$ points: no care burden, 2140 points: low care burden, 41 - 60 points: moderate care burden, and 61-88 points: high care burden. 
The items in the scale are generally for social and emotional fields, and a higher score indicates that the problems experienced are bigger. The Cronbach's alpha value of the scale is 0.83 (18). In our study, the Cronbach's alpha value of the burden Interview was found to be 0.88 .

\section{Variables of the study}

The dependent variables are the mean scores on the caregiver quality of life index-cancer scale and the scores on the burden interview. The independent variables are socio demographic characteristics and care-related characteristics.

\section{Collecting data}

The data were collected by face to face method. The data collection process was carried out in chemotherapy and oncology clinics. A quiet environment was created for the interview. The interview took an average of 20-25 minutes.

\section{Ethical Approval}

The required ethics committee approval was obtained from the ethics Committee of Harran University (Date: 07 September 2016, No: 74059997.050.01.04-161), the permission was obtained from the institution where the study was conduc-ted, and the informed consents were obtained from the indivi-duals providing care for the cancer patienst who agreed to participate in the study.

\section{Statistical analysis}

Statistical package for social sciences (SPSS) 16.0 package program was used to evaluate the data. Descriptive statistics (number, percentage, mean), Independents Samples t Test, Kruskal-Wallis Test, Mann Whitney U test were used for data analysis.

\section{Results}

The mean age of the caregiving individuals was $34.78 \pm$ 1.25 years and $52.5 \%$ of them were male, $66.9 \%$ of them were married, $20.0 \%$ of them were university graduates, $47.5 \%$ of them had incomes lower than their expenses and $60.0 \%$ of them were not employed (Table 1 ).

According to their their statements, $60.0 \%$ of the caregivers had difficulties in working life; $21.8 \%$ of them had previously provided care for another patient; $89.4 \%$ of them gave care because of family commitments/family bonds. The mean duration of caregiving was $2.35 \pm 2.16$ (1-12) years and $58.1 \%$ of them stated that there was another individual helping them during care. $98.1 \%$ of the caregivers were family members; $61.2 \%$ of them were affected negatively in terms of health; $43.1 \%$ of them had a deterioration in their mental health status; $95.6 \%$ of them fulfilled their responsibilities; $40.0 \%$ of them had difficulties in working life. It was found that $92.5 \%$ of them did not receive training about caregiving and $75.0 \%$ of those received training from health workers.

The mean score of the caregivers on the whole Burden Interview was $32.65 \pm 15.14$ and their mean score on the whole CQOLC was $78.75 \pm 16.31$ (Table 2).
Table 1. Demographic characteristics of caregivers $(n=160)$

\begin{tabular}{|c|c|c|}
\hline Variables & $\mathbf{n}$ & $\%$ \\
\hline \multicolumn{3}{|l|}{ Age } \\
\hline Under 45 years & 126 & 78.8 \\
\hline 45 years old & 34 & 21.3 \\
\hline \multicolumn{3}{|l|}{ Gender } \\
\hline Woman & 76 & 47.5 \\
\hline Male & 84 & 52.5 \\
\hline \multicolumn{3}{|l|}{ Marital status } \\
\hline Themarried & 107 & 66.9 \\
\hline Single & 53 & 33.1 \\
\hline \multicolumn{3}{|l|}{ Education status } \\
\hline Illiterate & 24 & 15.0 \\
\hline Literate & 6 & 3.8 \\
\hline Primary school & 30 & 18.8 \\
\hline Middle school & 22 & 13.8 \\
\hline High school & 46 & 28.8 \\
\hline Üniversity & 32 & 20.0 \\
\hline \multicolumn{3}{|l|}{ Income status } \\
\hline Income less than expense & 76 & 47.5 \\
\hline Income expense equal & 69 & 43.1 \\
\hline Income more than expense drum & 15 & 9.4 \\
\hline \multicolumn{3}{|l|}{ Employment Status } \\
\hline Employe & 63 & 39.4 \\
\hline Unemploye & 97 & 60.6 \\
\hline Total & 160 & 100.00 \\
\hline
\end{tabular}

Table 2. Burden interview and caregiver quality of life Index-cancer scale score averages

\begin{tabular}{lcl}
\hline Scales & $\overline{\mathbf{X}} \pm$ SD & Min-Max Points \\
\hline Burden Interview & $32.65 \pm 15.14$ & $5.00-83.00$ \\
$\begin{array}{l}\text { Total score } \\
\text { Caregiver Quality of Life Index-CancerScale }\end{array}$ \\
\hline Load & $68.77 \pm 28.12$ & $10.50-140.00$ \\
Discomfort & $93.96 \pm 29.12$ & $0.00-140.00$ \\
Positive adaptation & $83.59 \pm 29.48$ & $0.00-140.00$ \\
Financial troubles & $74.22 \pm 40.61$ & $0.00-140.00$ \\
Total Score & $78.75 \pm 16.31$ & $42.00-122.00$ \\
\hline
\end{tabular}

There was no significant difference between the mean scores of the caregiving individuals on the whole Burden Interview $(\mathrm{t}=-.928, \mathrm{p}=.355)$ and the whole CQOLC $(\mathrm{t}=$ $.717, p=.475)$ according to gender. While there was no statistically significant difference between the mean scores of the whole Burden Interview according to education level ( $K-W=2.426, p=.788)$, a statistically significant difference was found between the mean scores on the financial difficulty subscale of the CQOLC $(K-W=15.290 p=$ .009). There was no significant difference between the mean scores on the whole Burden Interview while there was a significant difference between the mean scores on the wole CQOLC scale according to income status ( $\mathrm{K}-\mathrm{W}=$ 4.180, $p=.124),(K-W=7.632 p=.022)$ (Table 3).

\section{Discussion}

Cancer is an important public health problem. This problem can be solved by a multi-step and very complex process (19). 
Table 3. Comparison of the mean scores on the burden interview and the caregiver quality of life index-cancer scale according to some characteristics of caregivers.

\begin{tabular}{|c|c|c|c|c|c|c|}
\hline \multirow{3}{*}{ Variables } & \multicolumn{6}{|c|}{ Scales } \\
\hline & \multirow{2}{*}{$\begin{array}{c}\text { Burden Inter- } \\
\text { view } \\
\overline{\mathrm{X}} \pm \mathrm{SD}\end{array}$} & \multicolumn{5}{|c|}{ Caregiver Quality of Life Index-Cancer Scale } \\
\hline & & $\begin{array}{c}\text { Burden } \\
\overline{\mathbf{X}} \pm S D\end{array}$ & $\begin{array}{c}\text { Disruptiveness } \\
\overline{\mathrm{X}} \pm \mathrm{SD}\end{array}$ & $\begin{array}{c}\text { Pozitive adapta- } \\
\text { tion } \\
\overline{\mathrm{X}} \pm \mathrm{SD}\end{array}$ & $\begin{array}{c}\text { Financial concern } \\
\bar{X} \pm S D\end{array}$ & $\begin{array}{l}\text { Total } \\
\bar{X} \pm S D\end{array}$ \\
\hline \multicolumn{7}{|l|}{ Age } \\
\hline Under 45 & $33.10 \pm 15.21$ & $66.77 \pm 28.25$ & $92.73 \pm 29.83$ & $86.19 \pm 27.93$ & $72.59 \pm 40.76$ & $77.93 \pm 16.67$ \\
\hline 45 years old & $31.00 \pm 14.98$ & $79.88 \pm 30.02$ & $98.52 \pm 26.27$ & $73.97 \pm 33.36$ & $80.29 \pm 40.08$ & $81.76 \pm 14.73$ \\
\hline Statistical value & $\begin{array}{l}\mathrm{t}=-.717 \\
\mathrm{p}=.474\end{array}$ & $\begin{array}{c}t=-2.549 \\
p=.012\end{array}$ & $\begin{array}{c}t=-1.029 \\
p=.305\end{array}$ & $\mathrm{t}=2.169 \mathrm{p}=.032$ & $\mathrm{t}=-.981 \quad \mathrm{p}=.328$ & $\begin{array}{c}t=-1.216 \\
p=.226\end{array}$ \\
\hline \multicolumn{7}{|l|}{ Gender } \\
\hline Woman & $31.48 \pm 14.66$ & $66.80 \pm 31.80$ & $96.77 \pm 29.91$ & $16.69 \pm 6.08$ & $79.67 \pm 40.65$ & $17.18 \pm 5.29$ \\
\hline Male & $33.71 \pm 15.58$ & $68.75 \pm 26.66$ & $91.42 \pm 28.33$ & $16.73 \pm 5.76$ & $69.30 \pm 40.18$ & $17.26 \pm 17.26$ \\
\hline Statistical value & $\begin{array}{c}\mathrm{t}=-.928 \\
\mathrm{p}=.355\end{array}$ & $\mathrm{t}=.011 \mathrm{p}=.991$ & $\begin{array}{c}t=1.161 \\
p=.247\end{array}$ & $\mathrm{t}=.453 \mathrm{p}=.965$ & $\mathrm{t}=1.620 \mathrm{p}=.107$ & $\mathrm{t}=.717 \mathrm{p}=.475$ \\
\hline \multicolumn{7}{|l|}{ Marital status } \\
\hline Themarried & $32.76 \pm 15.45$ & $20.42 \pm 8.28$ & $18.77 \pm 5.83$ & $15.94 \pm 6.04$ & $6.53 \pm 3.52$ & $17.40 \pm 4.51$ \\
\hline Single & $32.43 \pm 14.63$ & $18,07 \pm 8.24$ & $18.83 \pm 5.85$ & $18.28 \pm 5.30$ & $6.01 \pm 3.39$ & $16.86 \pm 5.66$ \\
\hline Statistical value & $\begin{array}{l}\mathrm{t}=-.130 \\
\mathrm{p}=.897\end{array}$ & $t=1.694 p=.092$ & $\mathrm{t}=-.056 \mathrm{p}=.956$ & $\mathrm{t}=-2.396 \quad \mathrm{p}=.018$ & $\mathrm{t}=.878 \quad \mathrm{p}=.381$ & $\mathrm{t}=.367 \quad \mathrm{p}=.714$ \\
\hline \multicolumn{7}{|l|}{ Education status } \\
\hline Illiterate & $35.25 \pm 15.91$ & $72.91 \pm 33.13$ & $93.33 \pm 25.56$ & $81.66 \pm 35.83$ & $5.29 \pm 4.02$ & $15.75 \pm 4.31$ \\
\hline Read and writed & $33.83 \pm 15.96$ & $71.75 \pm 26.72$ & $91.66 \pm 21.36$ & $71.66 \pm 27.14$ & $7.66 \pm 3.88$ & $18.33 \pm 4.36$ \\
\hline Primary school & $31.66 \pm 16.22$ & $75.13 \pm 31.73$ & $98.00 \pm 30.92$ & $74.83 \pm 35.97$ & $7.46 \pm 3.43$ & $17.80 \pm 5.41$ \\
\hline Middle school & $35.00 \pm 18.57$ & $65.54 \pm 28.64$ & $95.45 \pm 30.11$ & $86.59 \pm 28.92$ & $6.27 \pm 2.93$ & $17.90 \pm 4.55$ \\
\hline High school & $31.04 \pm 11.90$ & $65.43 \pm 26.16$ & $94.23 \pm 29.90$ & $91.84 \pm 20.58$ & $5.23 \pm 3.22$ & $18.06 \pm 4.83$ \\
\hline University & $32.12 \pm 15.73$ & $66.17 \pm 29.07$ & $89.68 \pm 30.79$ & $81.56 \pm 27.92$ & $7.56 \pm 3.16$ & $15.90 \pm 5.11$ \\
\hline Statistical value & $\begin{array}{c}\mathrm{K}-\mathrm{W}=2.426 \\
\mathrm{p}=.788\end{array}$ & $\begin{array}{c}\mathrm{K}-\mathrm{W}=2.235 \\
\mathrm{p}=.816\end{array}$ & $\begin{array}{c}\mathrm{K}-\mathrm{W}=1.696 \\
\mathrm{p}=.889\end{array}$ & $\begin{array}{c}\mathrm{K}-\mathrm{W}=6.726 \\
\mathrm{p}=.242\end{array}$ & $\begin{aligned} K-W & =15.290 \\
p & =.009\end{aligned}$ & $\begin{array}{c}\mathrm{K}-\mathrm{W}=2.693 \\
\mathrm{p}=.747\end{array}$ \\
\hline \multicolumn{7}{|l|}{ Income status } \\
\hline $\begin{array}{l}\text { Income less than ex- } \\
\text { pense }\end{array}$ & $35.13 \pm 13.97$ & $18.48 \pm 7.75$ & $17.94 \pm 5.32$ & $17.21 \pm 5.87$ & $5.19 \pm 3.55$ & $16.15 \pm 4.73$ \\
\hline Income expense equal & $30.52 \pm 15.98$ & $21.05 \pm 8.80$ & $19.46 \pm 6.23$ & $16.00 \pm 5.90$ & $7.59 \pm 3.04$ & $18.36 \pm 4.70$ \\
\hline $\begin{array}{l}\text { Income more than ex- } \\
\text { pense drum }\end{array}$ & $29.93 \pm 15.98$ & $19.06 \pm 8.37$ & $20.00 \pm 6.08$ & $17.53 \pm 6.03$ & $6.60 \pm 3.18$ & $17.40 \pm 5.82$ \\
\hline Statistical value & $\begin{array}{c}\mathrm{K}-\mathrm{W}=4,180 \\
\mathrm{p}=.124\end{array}$ & $\begin{array}{c}\mathrm{K}-\mathrm{W}=2.845 \\
\mathrm{p}=.241\end{array}$ & $\begin{array}{c}\mathrm{K}-\mathrm{W}=4.514 \\
\mathrm{p}=.105\end{array}$ & $\begin{array}{c}\mathrm{K}-\mathrm{W}=1.555 \\
\mathrm{p}=.460\end{array}$ & $\begin{array}{c}\mathrm{K}-\mathrm{W}=16.502 \\
p=.000\end{array}$ & $\begin{array}{c}K-W=7.632 \\
p=.022\end{array}$ \\
\hline \multicolumn{7}{|l|}{ Employment status } \\
\hline Employe & $32.30 \pm 14.68$ & $21.01 \pm 7.40$ & $18.42 \pm 5.97$ & $15.98 \pm 5.56$ & $6.68 \pm 3.23$ & $18.30 \pm 4.41$ \\
\hline Unemploye & $32.88 \pm 15.51$ & $18.76 \pm 8.97$ & $19.03 \pm 5.74$ & $17.19 \pm 6.08$ & $6.15 \pm 3.63$ & $16.52 \pm 5.11$ \\
\hline Statistical value & $\begin{array}{l}\mathrm{t}=-.238 \\
\mathrm{p}=.812\end{array}$ & $t=1.683 p=.094$ & $\mathrm{t}=-.638 \quad \mathrm{p}=.525$ & $\mathrm{t}=-1.272 \quad \mathrm{p}=.205$ & $\mathrm{t}=.937 \mathrm{p}=.350$ & $\mathrm{t}=1.039 \mathrm{p}=.300$ \\
\hline \multicolumn{7}{|l|}{ Maintenance time } \\
\hline 1 year -2 year & $31.73 \pm 16,04$ & $19.65 \pm 8.58$ & $19.04 \pm 6.12$ & $16.83 \pm 6.00$ & $6.45 \pm 3.56$ & $16.95 \pm 4.89$ \\
\hline 3 year -4 year & $32.66 \pm 12,27$ & $19.25 \pm 7.26$ & $18.50 \pm 5.11$ & $18.00 \pm 5.35$ & $6.12 \pm 3.63$ & $17.50 \pm 5.25$ \\
\hline 5 years and up & $37.40 \pm 12.56$ & $20.04 \pm 8.32$ & $17.81 \pm 4.98$ & $14.72 \pm 5.64$ & $6.13 \pm 2.96$ & $18.31 \pm 4.65$ \\
\hline Statistical value & $\begin{array}{c}\mathrm{K}-\mathrm{W}=3.638 \\
\mathrm{p}=.162\end{array}$ & $\begin{array}{c}\mathrm{K}-\mathrm{W}=0.414 \\
\mathrm{p}=.813\end{array}$ & $\begin{array}{c}\mathrm{K}-\mathrm{W}=2.278 \\
\mathrm{p}=.320\end{array}$ & $\begin{array}{c}\mathrm{K}-\mathrm{W}=3.661 \\
\mathrm{p}=.160\end{array}$ & $\begin{array}{c}\mathrm{K}-\mathrm{W}=0.407 \\
\mathrm{p}=.816\end{array}$ & $\begin{array}{c}\mathrm{K}-\mathrm{W}=1.288 \\
\mathrm{p}=.525\end{array}$ \\
\hline \multicolumn{7}{|c|}{ Negatively affected health } \\
\hline Yes & $35.02 \pm 15.07$ & $66.11 \pm 27.37$ & $89.20 \pm 29.59$ & $81.50 \pm 27.62$ & $71.28 \pm 39.69$ & $16.73 \pm 4.85$ \\
\hline No & $28.71 \pm 14.55$ & $73.20 \pm 31.57$ & $1.01 \pm 26.72$ & $87.08 \pm 32.30$ & $79.13 \pm 41.98$ & $18.05 \pm 4.93$ \\
\hline Statistical value & $t=2.594 p=.010$ & $t=-1.497 p=.136$ & $t=-2.727 p=.007$ & $t=-1.161 p=.247$ & $t=-1.186 p=.237$ & $t=-1.654 p=.100$ \\
\hline
\end{tabular}


In this study, it was found that the caregivers had a low caregiving burden. In a similar way, the studies reported that the caregivers had a low caregiving burden $(7,20)$. Contrarily, there are also studies which determined that the caregiving burden of the caregivers was high $(21,22)$. Low caregiving burden of the caregivers in our study can be explained by the fact that more than half of the caregivers received support from other individuals during caregiving. In the study, the caregiving burden of thr caregivers aged 45 years and younger was higher while no significant relationship was found between age and quality of life. Lim et al. (23) reported that age did not have an effect on quality of life. In the literature, it was found that there was no significant difference between age groups in terms of caregiving burden $(7,21,24,25)$. Cain and Wicks (26) and Takata et al. (27) found that the caregivers who were younger than 55 years experienced exhaustion more. Similar to this study, Tel et al. (28) found that the caregiving burden of the individuals under the age of 45 was high. In our study, we expected that the caregiving burden of caregivers under the age of 45 would be high.

No significant relationship was found between the educational status and caregiving burden of caregivers. Iconomou et al. (5) stated that caregiving burden increases as the level of education decreases. In contrast to this study, Orak ve Sezgin (7) found a significant relationship between education and caregiving burden. In the study, high caregiving burdens of the caregivers with low education level may be an indication that awareness about caregiving is not sufficient.

In this study, it was found that the income levels and employment status of the patients' relatives did not affect the caregiving burden. In other studies, it was similarly stated that care burden of caregivers is not affected by income $(7,20,21)$. In the study of Şahin et al. (29) no significant relationship was found between the employment status and caregiving burden of the caregivers. The results of the study were found to be consistent with the literature. While no difference was found between the caregiving burden of the caregivers according to the duration of caregiving, it was determined that the caregiving burden increased with the prolongation of the duration of caregiving. In other studies, it was stated that the caregiving burden increases as the duration of caregiving is prolonged $(7,28,30)$

In the study, the caregiving burden of thr caregivers aged In the study, it was found that more than half of the caregivers were affected negatively in terms of health while providing care for the patients, and nearly half of them had an impaired mental health status. In addition, a significant difference was found between the caregiving burdens of the caregiving individuals according to their status of being affected negatively in terms of health. The caregiving burden was higher in the individuals having negatively affected health due to providing caregiving according to their statements. In other studies, it was found that caregiving burden negatively affected the health of caregivers such as mental depression, anxiety, and deterioration in physical health $(5,6,31-36)$. In the literature, this situation was explained by physical wear of individuals who giving care for cancer patients, compromising in terms of personal live, diminishing social relations, adversely affected family interactions and financial difficulties (37). Therefore, the findings of our study are consistent with the literature.

Not only the caregiving burden of individuals providing care for cancer patients is affected but also their quality of life is also affected (32). In this study, more than half of the caregivers stated that they received support from other family members about caregiving, and almost all of them stated that they undertook caregiving because there was no one to take care of the patient. Atagün et al (38). reported that caregiving responsibility is generally undertaken by first-degree relatives of patients. In another study, it was reported that $71.7 \%$ of the caregivers shared the caregiving process with someone and the quality of life of the caregivers was higher when they shared the caregiving responsibility with other (32). We also determined that the quality of life of the caregivers was not at the desired level. Similarly, other researchers stated that the quality of life of the individuals providing care for patients decreased (16). This finding can be explained by the fact that the health of more than half of the caregivers stated that their health was negatively affected while almost all caregivers defined caregiving as a family responsibility. In our study, it was found that age did not affect the quality of life of the caregivers and the quality of life of the caregivers aged 45 years and younger was low. A study reported that the age of the caregivers affected their quality of life (39). Similar to our study, Tel et al. (28) found that the quality of life of the individuals aged under 45 years was low. In this study, the low life quality of the caregivers under 45 years is an expected result and can be explained by the high caregiving burden of them.

In the study, it was determined that the gender of the caregivers did not affect their quality of life. In contrast, other studies in the literature stated that gender affects life quality (39). Our findings may be as a result of the close numbers of male and female caregivers.

We found that the educational status of the caregivers did not affect the quality of life. Lim et al. (24) reported that educational status does not affect the quality of life. However, other study stated that the quality of life of caregivers is affected by their educational status (6) The results of this study may suggest that the caregivers had similar levels of awareness because they did not receive any professional support.

In this study, it was found that the duration of caregiving did not affect the quality of life; as the caregiving time was prolonged, the quality of life improved. In the literature, the quality of life of caregivers is adversely affected due to 
longer duration of care period and this effect is also negatively reflected in the care given to the patient $(9,28)$. The increase in the quality of life as a result of the prolonged duration of caregiving suggests that they accepted the current situation and adapt their lives for this situation. In addition, the existence of individuals providing support to caregivers may have had a positive impact on their quality of life.

\section{Conclusions}

In the study, it was found that the caregivers had a low level of care burden and their life quality was not at the desired level.In the study, it was found that the caregivers had a low level of care burden and their life quality was not at the desired level. It was also found that the care burden of caregiving individuals was affected by their negative perceptions about their health while income status affected life quality.

In line with these results, it can be recommended to disseminate education programs which are conducted by health professionals to raise awareness for increasing the quality of life and reducing the burden of care, and to conduct nursing studies to determine the general health status of caregivers.

Ethical Approval: The required ethics committee approval was obtained from the ethics Committee of Harran University (Date: 07 September 2016, No: 74059997.050.01.04-161), the permission was obtained from the institution where the study was conducted, and the informed consents were obtained from the individuals providing care for the cancer patienst who agreed to participate in the study.

Author Contributions:

Concept: S.C.G., F.E.

Literature Review: S.C.G., F.E.

Design : S.C.G., F.E.

Data acquisition: S.C.G., F.E.

Analysis and interpretation: S.C.G., F.E.

Writing manuscript: S.C.G., F.E.

Critical revision of manuscript: S.C.G., F.E.

Conflict of Interest: The authors declare that there are no conflicts of interest.

Financial Disclosure: Authors declared no financial support was received.

\section{References}

1. Çivi S, Kutlu R, Çelik HH. Depression status and the factors affecting the quality of life in the relatives of the patients with cancer. Gulhane Med J. 2011;53(4):248-53.

2. Kitrungrote $L$, Cohen MZ. Quality of life of family caregivers of patients with cancer: a literature review. Oncol Nurs Forum. 2006;33(3):625-32.

3. Lambert S, Girgis A, Lecathelinais C, Stacey F. Walking a mile in their shoes: anxiety and depression among partners and caregivers of cancer survivors at 6 and 12 months post-diagnosis. Support Care Cancer. 2013;21(1):75-85.

4. Given B, Wyatt G, Given C, Gift A. Sherwood P, Devoss D, Rahbar M. Burden and depression among caregivers of patients with cancer at the end of life. Oncol Nurs Forum. 2004;31(6):1105-17.

5. Iconomou G, Vagenakis AG, Kalofonos, HP. The informational needs, satisfaction with communication, and psychological status of primary caregivers of cancer patients receiving chemotherapy. Support Care Cancer. 2001;9(8):591-6.

6. Karabuga H, PInar R. Reliability and validity of Turkish version of the caregiver quality of life Index cancer scale. APJCP. 2013;14:4017-21.

7. Orak OS, Sezgin S. Kanser hastasına bakım veren aile bireylerinin bakım verme yüklerinin belirlenmesi. Psikiyatri Hemşireliği Dergisi. 2015;6(1):33-39.

8. Türkoğlu N, Kiliç D. Effects of care burdens of caregivers of cancer patients on their quality of life. APJCP. 2012;13(8):4141-45.

9. Erdoğan Z, Yavuz DE. Kanserli hastaların bakım vericilerinde yaşam kalitesi. Arşiv Kaynak Tarama Dergisi. 2014;23(4):726-736.

10. Çavuş D: Kanser hastalarının hemşireler tarafından verilen taburculuk eğitimine ilişkin değerlendirmelerinin belirlenmesi. Yüksek Lisans Tezi, İzmir: Dokuz Eylül Üniversitesi Sağlık Bilimleri Enstitüsü, 2008.

11. Aktaş E, Barış N, Hıdıroğlu S, Save D. Kemoterapi alan hastaların yakınlarının deneyimleri: niteliksel bir çalışma. Ege Üniversitesi Hemşirelik Fakültesi Dergisi. 2012;28(2):6378.

12. Özdemir FK, Şahin ZA, Küçük D. Kanserli çocuğu olan annelerin bakım verme yüklerinin belirlenmesi. Yeni Tıp Dergisi. 2009;26:153-58.

13. Miedema B, Easley J. Fortin P, Hamilton R, Mathews M. The economic impact on families when a child is diagnosed with cancer. Curr Oncol. 2008;15(4):173-78.

14. O'hara RE, Hull JG, Lyons KD, Bakitas M, Hegel MT, Li Z, Ahles TA. Impact on care giver burden of a patient focused palliative care intervention for patients with advanced cancer. Palliat Support Care. 2010;8(4):395-404.

15. Bevans MF, Sternberg EM. Care giver burden, stress, and heal the effects among family care givers of adult cancer patients. JAMA. 2012;307(4):398-403.

16. Weitzner MA, Jacobsen $P B$, Wagner $H$, Friedland J, Cox $C$. The caregiver quality of life Index-cancer (CQOLC) scale: development and validation of an instrument to measure quality of life of the family caregiver of patients with cancer. Qual Life Res. 1990;8:55-63.

17. Zarit SH, Reever KE, Bach-Peterson J. Relatives of the impaired elderly: correlates of feelings of burden. Gerontologist. 1980;20(6):649-655.

18. Erdem M. Bakım verme yükü ölçeği'nin Türkçe'ye uyarlanması geçerlilik ve güvenilirliği. Atatürk Üniversitesi Hemşirelik Yüksekokulu Dergisi. 2008;11(4):85-95.

19. Baykara O. Kanser tedavisinde güncel yöntemler. Balıkesir Sağlık Bilimleri Dergisi. 2016;5(3):158-159.

20. Koç Z, Sağlam Z, Çınarlı T. Kanser tanısı almış olan bireylere bakım veren hasta yakınlarının bakım verme yükü ile etkileyen faktörlerin belirlenmesi. Samsun Sağılı Bilimleri Dergisi. 2016;1(1):99-116.

21. Şahin $Z A$, Polat $H$, Ergüney $S$. Kemoterapi alan hastalara bakım verenlerin bakım verme yüklerinin belirlenmesi. Atatürk Üniversitesi Hemşirelik Yüksekokulu Dergisi. 2009;12(2):1-8.

22. Palos GA, Mendoza TR, Liao KP, Anderson KO, Garcia- 
Gonzalez A, Hahn K, Nazario A, Ramondetta Lois M, Valero V, Lynch GR, Jibaja-Weiss ML, Cleeland CS. Caregiver semptom burden: the risk of caring for an underserved patient with advanced cancer. Cancer. 2010;19:1-10.

23. Lim H, Tan J, Chua J, Yoong R, Lim S, Kua E, Mahendran R. Quality of life of family caregivers of cancer patients in Singapore and globally. Singapore Med. 2017;58(5):258261.

24. Sarıtaş SÇ, Bayır K, Sarıtaş S, Ucuzal M. (Caregivers of patients undergoing liver transplantation determination the burden of care. Yıldırım Beyazıt University Journal of Nursing. 2014;2(1):17-25.

25. Malak AT, Dicle A. Beyin tümörlü hastalarda bakım verenlerin yükü ve etkileyen faktörler. Türk Nöroşirürji Dergisi. 2008;18(2):118-121.

26. Cain CJ, Wicks MN. Caregiver attributes as correlates of burden in family caregivers coping with chronic obstructive pulmonary disease. Journal of Family Nursing. 2000;6:46-68.

27. Takata $S$, Washio $M$, Moriwaki $A$, Tsuda $T$, Nakayama $H$, Iwanaga $T$, Aizawa $H$, Arai $Y$, Nakanishi $Y$, Inoue, $H$. (2008). Burden among caregivers of patients with chronic obstructive pulmonary disease with long-term oxygen therapy. Int Med J. 2008;15:53-7.

28. Tel D, Demirkol D, Kara S, Aydın D. KOAH'lı hastaların bakım vericilerinde bakım yükü ve yașam kalitesi. Türk Toraks Dergisi. 2012;13(3):87-92.

29. Şahin ZA, Ergüney E. Determining reactions and anger expressions of family members giving care for receiving chemotherapy. Chemo Open Access. 2015;4:1-6.

30. Özdemir Ü, Taşcı $S$, Kartın $P$, Çürük GN, Nemli A, Karaca $H$. Kemoterapi alan bireylerin fonksiyonel durumu ve bakım verenlerin yükü. Erciyes Üniversitesi Sağlık Bilimleri Fakültesi Dergisi. 2017;4(1):49-61.

31. Yıldız E, Dedeli Ö, Pakyüz SÇ. Evaluation of care burden and quality of life among family caregivers of patients with cancer. Journal of Education and Research in Nursing. 2016;13(3):216-225.

32. Fridriksdottir N, Savarsdottir D, Halfdanardottir Si, Jonsdottir A, Magnusdottir H, Olafsdottir KL, Guðmundsdóttir $\mathrm{G}$, Gunnarsdóttir S. Family members of cancer patients: needs, quality of life and syptoms of anxiety and depression. Acta Oncol. 2001;50:252-58.

33. Chang EW, Tsai YY, Chang TW, Tsao CJ. Quality of sleep and quality of life in caregivers of breast cancer patient. Pschooncology. 2007;16(10):950-955.

34. Mystakidou K, Tsilika E, Parpa E, Galanos A, Vlahos L. Caregivers of advanced cancer patients: feelings of hopelessness and depression. Cancer Nurs. 2007;30(5):41218.

35. Bostancı N, Duruhan Ö, Eyüboğlu Ö, Sezgin Ö, Güvenir Ö Kanserli çocuğun bakım verenlerinde yasam kalitesi, depresyon ve anksiyete düzeyleri. Florence Nightingale Hemşirelik Dergisi. 2007;15(60):165-172.

36. Dökmen ZY. Yakınlarına bakım verenlerin ruh sağlıkları ile sosyal destek algıları arasındaki ilişkiler. Ankara Üniversitesi Sosyal Bilimler Enstitüsü Dergisi. 2012;3(1):3-38.

37. Yeşil $T$, Uslusoy $E$, Korkmaz $M$. Kronik hastalığı olanlara bakım verenlerin bakım yükü ve yaşam kalitesinin incelenmesi. Gümüşhane Üniversitesi Sağılı Bilimleri Dergisi. 2016;5(4):54-66.

38. Atagün Mi, Balaban ÖD, Atagün Z, Elagöz M, Özpolat AY.
Kronik hastalıklarda bakım veren yükü. Psikiyatride Güncel Yaklaşımlar. 2011;3:513-552.

39. Dumont S, Turgeon J, Allard P, Gagnon P, Charbonneau C, Vezina L. Caring for a loved one with advanced cancer: determinants of psychological distress in family caregivers. J Palliat Med. 2006;9:912-21. 